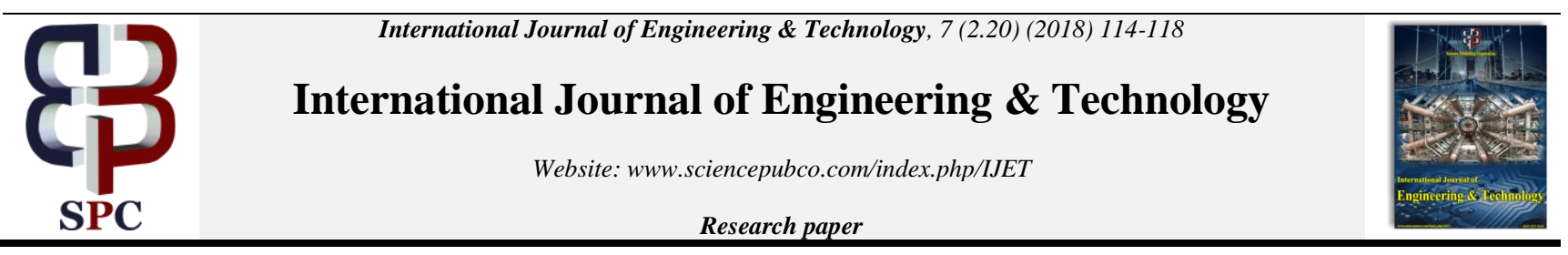

\title{
A Study on Marketing Strategies using Social Media in Facebook, Youtube, Pinterest
}

\author{
Dr. Sekhara Rao ${ }^{1 *}$, J. Sri Lakshmi ${ }^{2}$, Ch. Sahyaja ${ }^{3}$, G.Dimple $^{4}$ \\ ${ }^{1}$ Associate Professor, KLU Business School, sekharks@ kluniversity.in \\ ${ }^{2}$ Student, KLU Business School \\ ${ }^{3}$ Research Scholar, KLU Business School \\ ${ }^{4}$ Student, KLU Business School \\ *Corresponding author E-mail:Sahyaja.ch@gmail.com
}

\begin{abstract}
Social media is a key that will ensure An effective participation for Online networking and the organizations requirement should detract separate promoting hypotheses under thought Along these lines that they can support their brand in distinctive perspective. This research study analyses the impact of loyal customers of an organization. With developing number from claiming associations advertising extensive variety about decisions crosswise over that business constructed today's business All the more focused over ever preceding. Growing client devotion may be often recognized Likewise the enter driver for association's long expression reasonable showcasing victory. Recently, relationship promoting need created concerning illustration a champion around the practically fit. advertising devices to develop client devotion, communication and long haul engagement. Associations over the business are relying on relationship promoting to widen their piece of the overall industry by fortifying client connections and building client faithfulness.
\end{abstract}

Keywords: Social Media, Social Media Marketing, Customer Relationship, Loyal Customers, Digital Marketing, Reliability.

\section{Introduction}

Now a day's Social Media a boost to people in all ways. And for high businesses this study will represent an advertising chance that transcends those universal agent Furthermore associate organizations specifically for clients and customers.

\subsection{Social media marketing:}

Online networking promoting comprises for online networking will influence consumers something like one's company, results or benefits are worth-while. Online networking advertising will be characterized concerning illustration showcasing utilizing on the web communities, social networks, blog showcasing and a greater amount. Lazer and Kelly's (1973) characterize social showcasing as "worried about the utilization of advertising information, ideas, and techniques to upgrade social and in addition monetary closures" [1]. It is worried about the investigation of the social outcomes of showcasing strategies, choices and exercises."

1.3 Benefits of Social media marketing

Social media marketing helps in:

- To Generate exposure to all businesses.

- Increase of traffic/subscribers.

- To Build new business partnerships.

- And to Rise search engine rankings.

- To Generate qualified leads due to better lead generation efforts.

- To Sell more products and services. And reduction in overall marketing expenses

\section{Review of Literature}

Acc to Kartik Hosanagar, The results showed the content design strategies in social media, and the methodology.Face book enable companies to create profile pages and to post status updates, advertise new promotions, ask questions, interact with supermarkets and push content directly to consumers [2-4]. The study of kartik hosanagar describes as follows: "Consumers have more faith and feel closer to the company when interacting with supermarkets on face book. Online social networks, especially face book bring company closer to consumers and the other way around as well." The company will get more direct feedback from consumers through face book. So the author suggested that every specific store should open their own face book page to bring customers more closer. This Facebook page shows the facts about the company through posts, pictures, activities, comments, etc. As indicated ventually Tom's perusing Kaplan What's more Haenlein(2010) "Online systems administration may be a gathering about web develop requisitions that meets expectations in light of the ideological boundary Furthermore inventive establishments about Web 2. 0 , Also it permits the creation Also trade of customer processed. content". Fuller (2009) said that with the advances in the web and the rise of Web 2.0, the interconnectivity between people has developed the web. This improvement empowers clients and organizations to team up on the web [5-9]. This has risen through webbased social networking, which empower buyers to produce content and have social cooperations online by means of social stages. There are various social stages that have encouraged data sharing. For example, "Wikipedia, a free online reference book, is a standout amongst the most prominent stages and has the office for cli- 
ents to team up on data sharing (Chen 2011)."Other famous platforms such as Amazon, com, enable customers to review and rate products. In addition, Parts from claiming these platforms need aid helpfully reliant (Chris 2008). Those following era from claiming web organizations will be In light of groups - a great apparatus to new client fascination (Bagozzi \& Dholakia 2002; Ridings \& Gefen. 2004. As indicated by Gefen 2002) told this would significantly impact clients' aim to purchase and thusly, it is vital for organizations to have a plan of action adjusted to social trade (Lorenzo et al. 2007; Liang \&c Turban 2011). This examination social benefits of the business is another stream clinched alongside web based business, which energizes the social coordinated effort of clients through web-based long range interpersonal communication (Hajli 2013). Mrs. Smita Dayal (2016) assessed that Online networking sites (SMWs) for example, such that facebook, orkut ,youtube, twitter, and so forth they have picked up totally acknowledgement amongst web clients in the indian subcontinent. Mil-lions from claiming people over those reality got parts for these SMWs will associate What's more manufacture relationships, with different similar people [10]. In this investigation SMWs are utilized for shifted design similar to trading information, expressing over discussions, What's more interfacing will people, and so forth. (Kaplan and Haenlein,2010).

\subsection{Significance of the study}

Holding is essential in light of the fact that the Costs of Retaining Old Customers is Low. The cost of holding clients will differ by industry attempt, yet unmistakably maintenance is less expensive than procurement. In addition to the fact that it is less expensive to hold than gain, however the arrival on venture (ROI) is frequently higher as well. Steadfast clients have a tendency to spend more than new clients. Steadfast clients have a tendency to visit a retailer all the more regularly and furthermore make bigger and bigger buys. Holding a faithful client base is confirmation that the organization convey an incredible client benefit involvement. Potential customers will see that the company have repeat business and trust more from the start. Word-of-mouth advertising is still the most powerful form [11]. When the organization offers a great customer experience, fans want to share the brand with their family, friends, and colleagues.

\section{Research Gap}

Failing to Interact with the Followers and Fans of social media ( by Michelle sternbauer) .If the organizations ignore their guests, didn't take the time to ask about them or listen to them, and generally behaved as if the company was doing them a favour by letting them come to the company, That would be a threat for the organization in the long run and it can't sustain in the market. Social media marketing is an opportunity to build relationships, interact, and connect with the customers. If organization fails to maintain brand loyalty in the minds of loyal customers, there will be a chance of losing them and in turn that will affect sales.

\subsection{Research Objectives}

1. To study and gain insight into a community of interest

2. To investigate and build brand visibility and authority.

3. To study and build trust and to find ways to retain customers.

\subsection{Hypothesis}

H1: Falling on cooperation for clients will impact on the showcasing methodologies for Online networking..
H1.1: There is a impact of customer service provided by the social media and relationship marketing.

H1.2: There is a impact of access to share info on social media and word of mouth marketing.

H1.3: There will be a effect from claiming client administration Gave Eventually Tom's perusing those online networking Also differing qualities showcasing.

H1.4: There is a impact of access to share info on social media and email marketing.

\section{Research Methodology}

Research design is the course of action plans that are used for collection of the data. It is often necessary to includes a consideration of the concepts and theories which underlie in the methods. The process used to collect information for the purpose of making interaction level with customers, marketing strategies and other business decisions should be effective, efficient, executional \& empirical [12]. For the collection of data in this study, primary data sources are used. The methodology of the study is an extensive convenience sampling technique based on structured questionnaire method of surveying where a sample of 100 people from the desired location of India i.e. Vijayawada is considered during November-December 2017. It used direct interaction (face to face conversation) as the modes to get the data sheet filled. The data are further coded \&classified into tables for analysis and presentation considers the graphs and figures followed by the interpretation. This involves close-ended open ended questions with the Likert scale ( 5 point basis) as the measuring tool for the collected data which will be analysed to generate the conclusion. The study considers the population of Vijayawada who had an idea about social media marketing. The researcher approaches them through retail centres and business centres.

\section{Facebook - 144,860 \\ YouTube- 280,895 \\ Pinterest-96,851}

Through sampling method the study will take certain samples in the total population and perform data analysis. Here the study takes a sample of 100 members in 3 areas from total population.

\section{Data Analysis}

Table 1: which social media sites do you have an account on?

\begin{tabular}{|l|l|c|c|c|c|}
\hline \multicolumn{5}{|c|}{ Social Media } \\
\hline \multicolumn{2}{|c|}{} & $\begin{array}{c}\text { Frequen- } \\
\text { cy }\end{array}$ & $\begin{array}{c}\text { Per- } \\
\text { cent }\end{array}$ & $\begin{array}{c}\text { Valid } \\
\text { Per- } \\
\text { cent }\end{array}$ & $\begin{array}{c}\text { Cumula- } \\
\text { tive Per- } \\
\text { cent }\end{array}$ \\
\hline $\begin{array}{l}\text { Val- } \\
\text { id }\end{array}$ & $\begin{array}{l}\text { face } \\
\text { book }\end{array}$ & 57 & 57 & 57 & 57 \\
\cline { 2 - 6 } & $\begin{array}{l}\text { LinkedI } \\
\text { n }\end{array}$ & 6 & 6 & 6 & 63 \\
\cline { 2 - 6 } & $\begin{array}{l}\text { YouTub } \\
\text { e }\end{array}$ & 20 & 20 & 20 & 83 \\
\cline { 2 - 6 } & pinterest & 13 & 13 & 13 & 96 \\
\cline { 2 - 6 } & $\begin{array}{l}\text { not so- } \\
\text { cial } \\
\text { media } \\
\text { user }\end{array}$ & 4 & 4 & 4 & 100 \\
\cline { 2 - 6 } & Total & 100 & 100 & 100 & \\
\hline
\end{tabular}




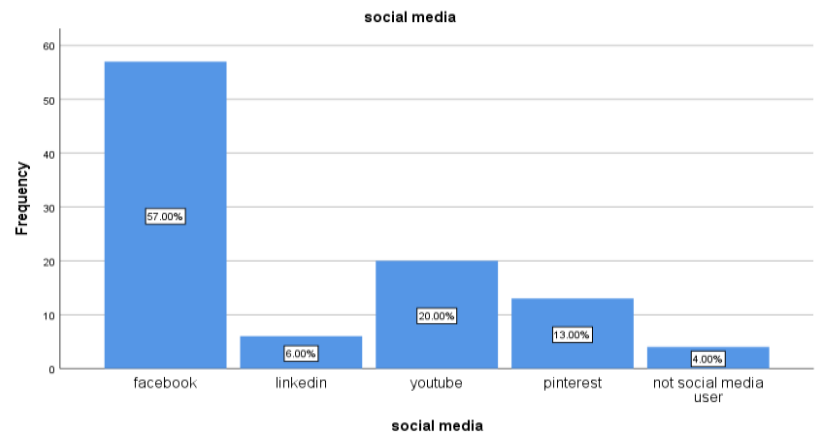

Figure 1: Figure shows the social media sites and its frequency

\section{Interpretation:}

The above statistics show that $57 \%$ of the respondents are using face book and $20 \%$ use YouTube followed by interest accounting $13 \%$. And only $4 \%$ of them do not have any account o the above following social network.

Table 2: Will you get advertisements and product info through emails (or) other mails available?

\begin{tabular}{|l|l|c|c|c|c|}
\hline \multicolumn{6}{|c|}{ Rate of advertisements of the products through mails } \\
\hline \multirow{2}{*}{} & Frequency & Percent & $\begin{array}{c}\text { Valid } \\
\text { Percent }\end{array}$ & $\begin{array}{c}\text { Cumulativ } \\
\text { e Percent }\end{array}$ \\
\hline Valid & not at all & 2 & 2 & 2 & 2 \\
\cline { 2 - 6 } & Rarely & 3 & 3 & 3 & 5 \\
\cline { 2 - 6 } \\
$\begin{array}{l}\text { less } \\
\text { frequently }\end{array}$ & 1 & 1 & 1 & 6 \\
\cline { 2 - 6 } & Frequently & 27 & 27 & 27 & 33 \\
\cline { 2 - 6 } & $\begin{array}{l}\text { more } \\
\text { frequently }\end{array}$ & 67 & 67 & 67 & 100 \\
\cline { 2 - 6 } & Total & 100 & 100 & 100 & \\
\hline
\end{tabular}

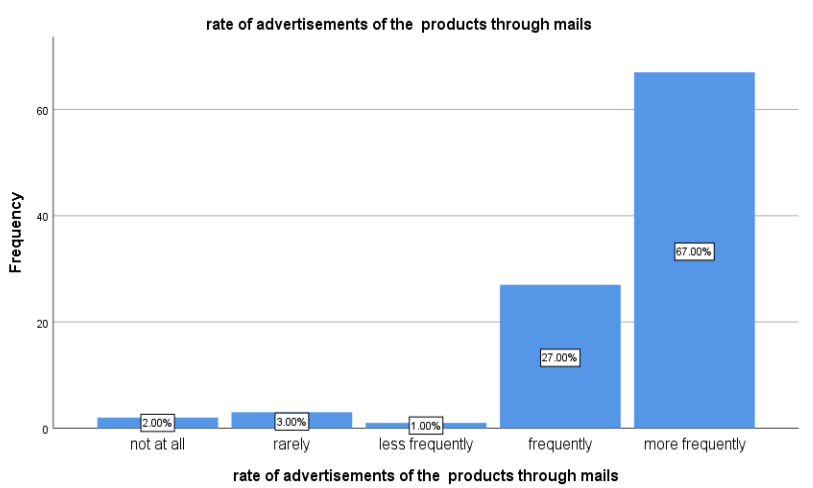

Figure 2: Figure shows the role of advertisements of the products through mails

\section{Interpretation:}

$67 \%$ of the respondents from the sample feel that they get advertisements and product info through emails very frequently and $27 \%$ felt they get frequently. $1 \%$ feels they get product info less frequently and $2 \%$ does not get any info through emails.
Table 3: There is a impact of customer service provided by the social media and relationship marketing.

\begin{tabular}{|c|c|c|c|c|c|c|c|}
\hline \multicolumn{8}{|c|}{$\begin{array}{l}\begin{array}{l}\text { Rate of customer service * rate of good relationship Cross } \\
\text { tabulation }\end{array} \\
\end{array}$} \\
\hline & & \multicolumn{5}{|c|}{ rate of good relationship } & \multirow[b]{2}{*}{$\begin{array}{l}\text { To- } \\
\text { tal }\end{array}$} \\
\hline & & $\begin{array}{c}\text { stron } \\
\text { gly } \\
\text { disa- } \\
\text { gree } \\
\end{array}$ & $\begin{array}{l}\text { disa- } \\
\text { gree }\end{array}$ & $\begin{array}{c}\text { nei- } \\
\text { ther } \\
\text { agree } \\
\text { nor } \\
\text { disa- } \\
\text { gree }\end{array}$ & $\begin{array}{c}\text { Agr } \\
\text { ee }\end{array}$ & $\begin{array}{c}\text { stron } \\
\text { gly } \\
\text { agree }\end{array}$ & \\
\hline \multirow{5}{*}{$\begin{array}{l}\text { rate } \\
\text { of } \\
\text { cus- } \\
\text { tomer } \\
\text { ser- } \\
\text { vice }\end{array}$} & $\begin{array}{l}\text { not at } \\
\text { all }\end{array}$ & 0 & 0 & 0 & 0 & 2 & 2 \\
\hline & rarely & 0 & 0 & 0 & 0 & 3 & 3 \\
\hline & $\begin{array}{l}\text { less } \\
\text { fre- } \\
\text { quent- } \\
\text { ly }\end{array}$ & 0 & 0 & 0 & 3 & 4 & 7 \\
\hline & $\begin{array}{l}\text { fre- } \\
\text { quent- } \\
\text { ly }\end{array}$ & 1 & 0 & 3 & 0 & 23 & 27 \\
\hline & $\begin{array}{l}\text { more } \\
\text { fre- } \\
\text { quent- } \\
\text { ly }\end{array}$ & 0 & 2 & 3 & 16 & 40 & 61 \\
\hline \multicolumn{2}{|l|}{ Total } & 1 & 2 & 6 & 19 & 72 & $\begin{array}{c}10 \\
0\end{array}$ \\
\hline
\end{tabular}

Table 4: Table shows the Chi-Square test

\begin{tabular}{|l|c|c|c|}
\hline \multicolumn{4}{|c|}{ Chi-Square Tests } \\
\hline & & & $\begin{array}{c}\text { Asymptoti } \\
\text { c } \\
\text { Significanc } \\
\text { e (2-sided) }\end{array}$ \\
\hline $\begin{array}{l}\text { Pearson Chi- } \\
\text { Square }\end{array}$ & $17.613^{\mathrm{a}}$ & 16 & 0.04 \\
\hline $\begin{array}{l}\text { Likelihood } \\
\text { Ratio }\end{array}$ & 23.991 & 16 & 0.09 \\
\hline $\begin{array}{l}\text { Linear-by- } \\
\text { Linear } \\
\text { Association }\end{array}$ & 1.239 & 1 & 0.266 \\
\hline $\begin{array}{l}\text { N of Valid } \\
\text { Cases }\end{array}$ & 100 & & \\
\hline
\end{tabular}

\section{Interpretation}

Here the asymptotic significance is 0.040 which is less than 0.050 , so we reject the null hypothesis and accept alternative hypothesis which implies that there is significant association between the rate of customer service and the rate of good relationship. Hence, it can be propounded that the customers of Vijayawada are reliant to customer service provided by social media. This shows that people feel that social media gives positively implied for customer service.

Table 5: There is an impact of access to share info on social media and word of mouth marketing. 


\begin{tabular}{|c|c|c|c|c|c|c|c|}
\hline \multicolumn{8}{|c|}{$\begin{array}{l}\text { Rate of access to share the info on social media * rate of discussion with friends } \\
\text { family relatives }\end{array}$} \\
\hline \multicolumn{8}{|c|}{ Crosstab } \\
\hline & & \multicolumn{5}{|c|}{ rate of discussion with friends family relatives } & \multirow[b]{2}{*}{ Total } \\
\hline & & not at all & rarely & $\begin{array}{c}\text { less } \\
\text { frequently }\end{array}$ & frequently & $\begin{array}{c}\text { more } \\
\text { frequently }\end{array}$ & \\
\hline \multirow{5}{*}{$\begin{array}{l}\text { rate of } \\
\text { access to } \\
\text { share the } \\
\text { info on } \\
\text { social } \\
\text { media }\end{array}$} & not at all & 0 & 1 & $\overline{0}$ & 1 & 2 & 4 \\
\hline & rarely & 2 & 3 & 0 & 0 & 2 & 7 \\
\hline & $\begin{array}{l}\text { less } \\
\text { frequently }\end{array}$ & $\overline{0}$ & 1 & 7 & 0 & 0 & 8 \\
\hline & frequently & 0 & $\overline{0}$ & 0 & 24 & 4 & 28 \\
\hline & $\begin{array}{l}\text { more } \\
\text { frequently }\end{array}$ & 0 & 0 & 0 & 2 & 51 & 53 \\
\hline \multicolumn{2}{|l|}{ Total } & 2 & 5 & 7 & 27 & 59 & 100 \\
\hline
\end{tabular}

Table 6: Table shows the chi-square test

\begin{tabular}{|l|c|c|c|}
\hline & \multicolumn{4}{|c|}{ Chi-Square Tests } \\
\hline & Value & Df & $\begin{array}{c}\text { Asymptotic } \\
\text { Significance } \\
\text { (2-sided) }\end{array}$ \\
\hline $\begin{array}{l}\text { Pearson Chi- } \\
\text { Square }\end{array}$ & $21.492^{\mathrm{a}}$ & 16 & 0.04 \\
\hline $\begin{array}{l}\text { Likelihood } \\
\text { Ratio }\end{array}$ & 27.349 & 16 & 0.02 \\
\hline $\begin{array}{l}\text { Linear-by- } \\
\text { Linear Asso- } \\
\text { ciation }\end{array}$ & 47.948 & 1 & 0 \\
\hline $\begin{array}{l}\text { N of Valid } \\
\text { Cases }\end{array}$ & 100 & & \\
\hline
\end{tabular}

Here the asymptotic significance is 0.040 which is less than 0.050 , so we reject the null hypothesis and accept alternative hypothesis which implies that there is significant association between the rate of access to share info on social media and the rate of discussion about the marketing info you see on social media with friends, family(or)others. Hence, it can be propounded that the customers of Vijayawada are reliant to access to share info on social media.

Table 7: There is a impact of customer service provided by the social media and diversity marketing.

\begin{tabular}{|c|c|c|c|c|c|c|c|}
\hline \multicolumn{8}{|c|}{ Crosstab } \\
\hline & & \multicolumn{5}{|c|}{ rate of information of the products in social media } & \multirow[b]{3}{*}{ Total } \\
\hline & & & & \begin{tabular}{c|c|} 
less \\
fent1
\end{tabular} & frequentl] & $\begin{array}{c}\text { more } \\
\text { freguentl }\end{array}$ & \\
\hline & & not at all & Rarely & $\mathrm{y}$ & $\mathrm{y}$ & $\mathrm{y}$ & \\
\hline \multirow{5}{*}{$\begin{array}{l}\text { rate of } \\
\text { customer } \\
\text { service }\end{array}$} & not at all & 0 & 0 & 0 & 0 & 2 & 2 \\
\hline & rarely & $\overline{0}$ & 0 & 0 & $\overline{0}$ & 3 & 3 \\
\hline & $\begin{array}{l}\text { less } \\
\text { frequentl }\end{array}$ & 0 & 0 & 0 & 0 & 7 & 7 \\
\hline & frequentl & 0 & 0 & 0 & 0 & 27 & 27 \\
\hline & $\begin{array}{l}\text { more } \\
\text { frequentl }\end{array}$ & 1 & 3 & 5 & 17 & 35 & 61 \\
\hline \multicolumn{2}{|l|}{ Total } & 1 & 3 & 5 & 17 & 74 & 100 \\
\hline
\end{tabular}

Table 8: Table shows the chi-square test

\begin{tabular}{|l|c|c|c|}
\hline \multicolumn{4}{|c|}{ Chi-Square Tests } \\
\hline & Value & Df & $\begin{array}{l}\text { Asymptotic } \\
\text { Significanc } \\
\text { e (2-sided) }\end{array}$ \\
\hline $\begin{array}{l}\text { Pearson } \\
\text { Chi-Square }\end{array}$ & $22.463^{\mathrm{a}}$ & 16 & 0.129 \\
\hline $\begin{array}{l}\text { Likelihood } \\
\text { Ratio }\end{array}$ & 31.38 & 16 & 0.012 \\
\hline $\begin{array}{l}\text { Linear-by- } \\
\text { Linear } \\
\text { Association }\end{array}$ & 10.361 & 1 & 0.001 \\
\hline $\begin{array}{l}\text { N of Valid } \\
\text { Cases }\end{array}$ & 100 & & \\
\hline
\end{tabular}

Here the asymptotic significance is 0.129 which is greater than 0.050 , so we reject the alternative hypothesis and accept null hypothesis which implies that there is no significant association between the rate of customer service and the rate of information of the product in social media. Hence, a conclusive affirmation about the customer service and the information provided by social media about a product has impact on the customers.

Table 9: There is an impact of access to share info on social media and email marketing.

\begin{tabular}{|l|l|c|c|c|c|c|}
\hline \multicolumn{7}{|c|}{ Rate of access to share the info on social media * rate of advertisements of the } \\
products through mails \\
\hline \multicolumn{7}{|c|}{ Crosstab } \\
\hline
\end{tabular}

Table 10: Table shows the chi-square test

\begin{tabular}{|l|c|c|c|}
\hline & Chi-Square Tests \\
\hline & Value & Df & $\begin{array}{c}\text { Asymptotic } \\
\text { Significance (2- } \\
\text { sided) }\end{array}$ \\
\hline $\begin{array}{l}\text { Pearson Chi- } \\
\text { Square }\end{array}$ & $69.165^{\mathrm{a}}$ & 16 & 0.426 \\
\hline $\begin{array}{l}\text { Likelihood } \\
\text { Ratio }\end{array}$ & 72.504 & 16 & 0.137 \\
\hline $\begin{array}{l}\text { Linear-by- } \\
\text { Linear } \\
\text { Association }\end{array}$ & 3.32 & 1 & 0.068 \\
\hline $\begin{array}{l}\text { N of Valid } \\
\text { Cases }\end{array}$ & 100 & & \\
\hline
\end{tabular}

Here the asymptotic noteworthiness will be 0.426 which is more terrific over 0.050 , with the goal we reject those exchange theory and acknowledge invalid hypothesis which intimates that there may be no noteworthy. association between the rate of access to share the info on social media and the rate of advertisements of products through mails. Hence, it indicates that the customers don't reply, believe and use the advertisements of products through mails.

\section{Findings \& Suggestions}

1. From the survey it is concluded that about $96 \%$ respondents using social media such as Facebook, YouTube etc, and only $4 \%$ does not use any of the social media networks.

2. Of late, Relationship advertising need risen Similarly as a standout amongst the vast majority capable showcasing instruments with grow client loyalty, connection Furthermore long expression engagement.

3. Organizations across the industry are depending upon relationship marketing to broaden their market share by strengthening customer relationships and building customer loyalty.

\section{Suggestions}

1. The study shows that online marketing is gaining prominence and wide usage around the Indian economy as well as Vijayawada in AP. Hence, the digital marketing approach for this 
location is also a strategic and fruitful option to tap on the market.

2. The sample of 100 respondents is a small and minute consideration but the precision and the accuracy of the results shows that we can plan a focused budget and proactive strategies of communicating to the customers by using the social media.

3. The demographic aspects are to be greatly considered while making the market entry/growth policies where the people of Vijayawada are very optimistic with good purchasing power and spending psychology since more than $90 \%$ of major use electronic gadgets and are connected with internet via social media.

\section{Conclusion}

In the synopsis of this study after critically gauging and interpreting in purview of the data, charts, figures, hypothesis tests, findings and suggestions, this study would like to clinch that the alternative hypothesis (H1): Failing to interact with customers will effect on the marketing strategies in social media, formed as the ideation of this pursuit has been accepted with majority since 11 different parametric Chi-Square tests verifies its acceptance. Also more than $68 \%$ of the samples from Vijayawada as seen in the response collected, to prove interaction with customers will have impact on marketing strategies in social media. There is no getting away web-based social networking nowadays, either for people or for organizations. Today, it is difficult to isolate web-based social networking from the online world. Organizations are redirecting assets and reexamining their customary effort techniques. What's more, as the online networking wave disperses into the tremendous sea of associated encounters, the term itself will turn into a passage in lexicons and reference books and we will leave on another period of learning, openness and encounters unbound by separation, time or physical dividers.

\section{References}

[1] Lazer, W., Kelley, E.J. (1973). Social Marketing: Perspectives and Viewpoints. Homewood: Richard D. Irwin

[2] Michael A. Stelzner (2010), Social Media Marketing Industry Report, "How Marketers are using social media to grow their businesses", Social Media Examiner

[3] Nora Ganim Barnes, Eric Mattson (2008, "Still Setting the Pace in Social Media: The First Longitudinal Study of Usage by the Largest US Charities", University of Massachusetts Dartmouth Center for Marketing Research,

[4] Social Media in India - An Overview by techiedevil on June 11, 2010 in Social Media.

http://www.internetmarketingjournal.org/social-media-india/

[5] Michael A. Seltzer (2010), Social Media Marketing Industry Report, "How Marketers are using social media to grow their businesses", Social Media Examiner, April 2010

[6] Philip Kotler, Management Marketingului, Editia a V-a, Editura Teora, 2008, Bucuresti

[7] Kaplan, Andreas M.; Michael Haenlein (2010). "Users of the world, unite! The challenges and opportunities of Social Media". Business Horizons 53 (1): 59-68

[8] Angella J. Kim and Eunju Ko(2012),” Do social media marketing activities enhance customer equity? An empirical study of luxury fashion brand" Journal of Business Research, 2012, vol. 65 , issue $10,1480-1486$

[9] Dayal, S. (2016). Skill Development Landscape in India. IRA International Journal of Education and Multidisciplinary Studies (ISSN 2455-2526), 3(3).

[10] Chen, I.-C., Hill, J.K., Ohlemüller, R., Roy, D.B. \& Thomas, C.D. (2011) "Rapid Range Shifts of Species Associated with High Levels of Climate Warming. Science", 333, 1024-1026.

[11] Richard P. Bagozzi ,Utpal M. Dholakia(2002)," Intentional social action in virtual communities", Volume16, Issue2, Pages 221.
[12] Catherine M. Ridings ,David Geffen(2006)," Virtual Community Attraction: Why People Hang Out Online", Volume10, Issue1. 